\title{
Upaya Pemberdayaan Ekonomi, Sosial dan Budaya pada Masyarakat Melalui Pengembangan Bisnis Ekowisata
}

\author{
Eldi Mulyana \\ Institut Pendidikan Indonesia Garut \\ Jl. Terusan Pahlawan No.83, Sukagalih, Tarogong Kidul, Kabupaten Garut, Jawa Barat \\ eldimulyana@institutpendidikan.ac.id
}

\begin{abstract}
Abstrak-Bisnis industri pariwisata memang menjadi primadona dan semakin menjanjikan. Bertambahnya minat wisatawan asing dan dalam negeri untuk travelling ke Indonesia. Beberapa faktor selain dikarenakan keindahan destinasinya yang menawarkan keindahan panorama alam, tak lain karena kemudahan pembelian tiket transportasi, hotel hingga paket wisata. Peluang besar ini banyak dimanfaatkan sebagai ajang bisnis pada sektor pariwisata. Terlebih juga bisa meningkatkan perekonomian di daerah. Namun demikian, membangun pariwisata mengharuskan banyak aktivitas yang dapat membawa dampak negatif pada lingkungan. Karena itu, untuk meminimalisir resiko dampak negatif dari pembangunan industri pariwisata adalah dengan mengimplementasikan pembangunan bisnis ecotourism atau sustainable tourism development dalam bentuk ekowisata. Penerapan pembangunan pariwisata yang ramah lingkungan yang disesuaikan dengan kearifan lokal dan kecerdasan spatial setempat dapat diukur keberhasilannya melalui siklus sumberdaya alam dan lingkungan di mana proses ekonomi dapat memberikan keuntungan secara berkelanjutan. Apabila pendekatan ekowisata diterapkan dengan baik maka industri pariwisata berpotensi untuk memberikan keuntungan secara berkelanjutan. Jika pendekatan ekowisata diterapkan dengan baik maka industri pariwisata berpotensi untuk memberikan dampak positif yang menguntungkan bagi lingkungan. Hal tersebut dapat dilakukan melalui upaya-upaya perlindungan dan konservasi lingkungan di mana pariwisata dapat menjadi sumber untuk perlindungan sumberdaya lingkungan dan meningkatkan nilai ekonomi. Selain itu, perlindungan terhadap sumberdaya lingkungan dapat bermanfaat pada pemberdayaan dalam bidang sosial dan budaya pada masyarakat yang ada di sekitarnya.
\end{abstract}

Kata Kunci- ekowisata, pariwisata, bisnis, ekonomi, sosial, budaya.

I. PENDAHULUAN

Pariwisata di Indonesia memiliki nilai dan keuntungan yang signifikan bagi kemajuan ekonomi lokal dan global karena itu sektor pariwisata ini digolongkan sebagai industry terbesar di dunia dan merupakan sektor ekonomi yang memiliki pertumbuhan yang sangat cepat dan penyedia lapangan pekerjaan yang banyak. Sumber ekonomi dan lapangan pekerjaan ini dapat dilihat dari travel, akomodasi, rumah makan, catering, layanan wisata, dan berbagai usaha kecil. Berdasarkan laporan dari World Trade and Tourism Council (WTTC) tahun 2018 bahwa sektor pariwisata Indonesia mencatat pertumbuhan tertinggi dengan menduduki peringkat ke-9 di dunia. Menteri Pariwisata Arief Yahya menyambut baik rangking yang dikeluarkan WTTC. Hal ini menurut Arief dapat lebih memperkuat posisi pariwisata Indonesia sebagai bagian penting dari perekonomian.
Pariwisata sebagai core economy, kini menjadi tujuan bersama, tak hanya segenap insan Kemenpar, tapi juga bagi seluruh bangsa Indonesia. Dalam beberapa tahun ke depan kita akan bertransformasi menjadi sebuah negara besar yang sebagian ekonominya didukung sektor pariwisata. Laporan WTTC juga menambahkan bahwa di kebanyakan Negara, wisata pesisir merupakan industry wisata terbesar dan memberikan kontribusi yang signifikan bagi PDB. Sebagai salah satu sektor ekonomi penting maka pariwisata memiliki dampak yang berlipat ganda, baik positif dan negatif, bagi manusia dan lingkungan. Secara garis besar dampak industri pariwisata dapat digolongkan ke dalam tiga dampak, yakni dampak lingkungan, dampak sosial-budaya dan dampak ekonomi.

\section{PENGEMBANGAN BISNIS EKOWISATA}


Pengembangan kepariwisataan dewasa ini, mulai diarahkan pada penggalian obyek-obyek wisata alam yang belum berkembang atau belum digali. Hal ini dilakukan dengan tujuan untuk menjaring wisatawan yang sudah mulai berubah dalam orientasi kegiatan wisatanya melalui Special Interest Tourism atau Alternative Tourism. Kecenderungan dewasa ini menunjukkan para wisatawan dalam dan luar negeri lebih memilih pada jenis wisata minat khusus. Pengembangan obyek wisata ini menjadi sangat penting artinya terutama pada era otonomi daerah yang berguna sebagai percepatan perekonomian di daerah.

Suatu obyek wisata yang akan dikembangkan, wajib dilakukan pengkajian oleh para ahli secara multidisipliner, integrasi dan lintas sektoral. Hal ini dilakukan untuk mencegah pengembangan obyek wisata yang hanya menitikberatkan pada eksploitasi keindahan dan keuntungan semata tanpa mempertimbangkan dampak negatif dari hasil pengembangan tersebut. Pengembangan obyek wisata yang berwawasan lingkungan merupakan wisata alternatif sebagai upaya untuk mengantisipasi menurunnya kepopuleran pariwisata massal.

Ekowisata merupakan kegiatan wisata yang menaruh perhatian besar terhadap kelestarian sumberdaya pariwisata. Di dalam etika suatu perencanaan dan pengembangan bisnis ekowisata, terdapat tiga perspektif yang perlu diperhatikan, yaitu:

1. Ekowisata sebagai produk

2. Ekowisata sebagai pasar

3. Ekowisata sebagai pendekatan pengembangan

Berdasarkan perspektif di atas maka jelaslah bahwa ekowisata merupakan salah satu produk alternatif kegiatan wisata yang memberikan daya tarik tersendiri, pangsa pasar yang berbeda dengan pemasaran wisata lainnya, dan upaya-upaya yang harus dilakukan dalam perencanaan dan pengembangannya pun sangat berbeda dengan jenisjenis wisata lainnya. Bisnis ekowisata merupakan produk wisata yang lebih menitikberatkan pada aspek pendidikan dan informasi, aspek sosial, estetika, aspek etika dan reputasi. Karena itu, di dalam perencanaan bisnis ekowisata harus diarahkan pada konsep, prinsip dan analisis pasar tersebut.

Menurut From (2004) terdapat tiga konsep ekowisata, yaitu: bersifat outdoor; akomodasi yang dicipta dan dikelola masyarakat lokal; dan memiliki perhatian terhadap lingkungan alam dan budaya lokal. Karena itu, kegiatan bisnis ekowisata memiliki prinsipprinsip sebagai berikut:

1. Mengurangi dampak negatif

2. Membangun kesadaran dan penghargaan
3. Menawarkan pengalaman-pengalaman positif

4. Memberikan keuntungan finansial

5. Meningkatkan kepekaan terhadap situasi sosial dan lingkungan

6. Menghormati HAM

Berdasarkan prinsip-prinsipnya maka kegiatan bisnis ekowisata merupakan kegiatan wisata yang menaruh perhatian besar terhadap kelestarian sumberdaya pariwisata. Karena itu, kegiatan bisnis ekowisata sangat berbeda dengan kegiatan wisata lainnya yang lebih bersifat massal. Berikut adalah karakteristik dari kegiatan bisnis ekowisata:

1. Aktivitas wisata berkaitan dengan konservasi lingkungan

2. Penyedia jasa menyiapkan atraksi dan menawarkan wisatawan untuk menghargai lingkungan

3. Kegiatan wisata berbasis alam

4. Tour operator menunjukkan tanggung jawab finansial dalam pelestarian lingkungan

5. Mengumpulkan dana untuk kegiatan pelestarian lingkungan

6. Penggunaan transportasi dan akomodasi lokal, bersifat sederhana, hemat energi, dan melibatkan partisipasi masyarakat

7. Berskala kecil

Selain karakteristik kegiatannya, ekowisata juga memiliki pasar dengan karakteristik wisatawannya, sebagai berikut:

1. Berusia 15-54 tahun

2. $50 \%$ adalah perempuan

3. $85 \%$ berpendidikan tinggi

4. Kelompok kecil atau individual

5. Memiliki durasi perjalanan yang panjang (8-14 hari)

6. Membelanjakan uangnya lebih besar

7. Kawasan alam bebas

8. Menikmati pemandangan dan mencari pengalaman baru

Memperhatikan bisnis ekowisata sebagai salah satu wisata yang memiliki produk dan pasar tersendiri, maka dalam upaya pengembangannya perlu memperhatikan berbagai pertimbangan dalam perencanaannya. Beberapa pertimbangan yang perlu diperhatikan adalah sebagai berikut:

1. Pengembangan produk wisata bernilai ekologi tinggi

2. Seleksi kawasan wisata yang menawarkan keanekaragaman hayati

3. Pengabaian produk dan jasa yang banyak mengkonsumsi energi dan menimbulkan limbah 
4. Standarisasi dan sertifikasi produk wisata berbasis ekologi

5. Pelatihan dan penguatan kesadaran lingkungan di kalangan warga masyarakat

6. Pelibatan penduduk lokal dalam kegiatan penyediaan dan pengelolaan jasa wisata

7. Kolaborasi manajemen trans-sektoral dalam pengembangan

Menurut Low Choy dan Heilbornn (1996), merumuskan lima faktor batasan yang mendasar dalam penentuan prinsip utama bisnis ekowisata, yaitu:

1. Lingkungan; ecotourism bertumpu pada lingkungan alam, budaya yang relatif belum tercemar atau terganggu

2. Masyarakat; ecotourism harus memberikan manfaat ekologi, sosial dan ekonomi langsung kepada masyarakat

3. Pendidikan dan pengalaman; ecotourism harus dapat meningkatkan pemahaman akan lingkungan alam dan budaya dengan adanya pengalaman yang dimiliki

4. Berkelanjutan; ecotourism dapat memberikan sumbangan positif bagi keberlanjutan ekologi lingkungan baik jangka pendek maupun jangka panjang;

5. Manajemen; ecotourism harus dikelola secara baik dan menjamin sustainability lingkungan alam, budaya yang bertujuan untuk peningkatan kesejahteraan sekarang maupun generasi mendatang

\section{UPAYA PEMBERDAYAAN EKONOMI, SOSIAL DAN BUDAYA PADA \\ MASYARAKAT MELALUI PENGEMBANGAN BISNIS EKOWISATA}

Pariwisata adalah salah satu faktor pembangunan yang dapat dilihat secara terpisah. Pembangunan di dalamnya juga terkait dengan sektor lain. Misalnya, pendidikan di bidang ini. Permasalahan dan kendala yang dihadapi sektor pendidikan antara lain mutu masukan, sumber daya termasuk di dalamnya adalah masalah pendidik, proses belajar pembelajaran, pengelolaan yang kurang efektif dan efisien, hasil belajar yang kurang efektif diharapkan serta tingkat income yang kurang memadai dan masih banyak lagi.

Berdasarkan hasil penelitian Ibrahim Musa dkk. Bahwa Indonesia telah meletakkan pariwisata sebagai salah satu sektor penting untuk mempercepat proses pembangunan nasional yang berkelanjutan. Namun kenyataannya, konsep bisnis pariwisata, bisnis pariwisata berkelanjutan di Indonesia masih mengalami banyak kendala baik dalam perencanaan maupun pelaksanaannya. Kendala tersebut terutama terletak pada masalah-masalah substansial seperti esensi pariwisata berkelanjutan itu sendiri, pengembangan produk, pasar dan pemasaran, serta dampaknya bagi berbagai lapisan masyarakat. Akar permasalahan dari kondisi tersebut sudah jelas, yaitu belum adanya kebijakan bisnis pariwisata yang jelas dan terpadu.

Bisnis ekowisata merupakan salah satu wisata alternatif dianggap salah satu cara untuk meningkatkan kehidupan ekonomi masyarakat pedesaan karena dianggap bisa memberikan kesempatan kerja, kesempatan berusaha, serta meningkatkan pengembangan kemampuan berusaha (Scheyvens, 2000), serta memberikan kesempatan yang lebih besar untuk mengontrol penggunaan sumber daya alam di daerah tertentu sebagai salah satu aset kegiatan bisnis ekowisata (Ashley \& Roe, 1997).

Bisnis ekowisata merupakan suatu kegiatan yang memanfaatkan sumber-sumber alam atau daerahdaerah yang relatif belum berkembang (sekaligus dengan budaya aslinya) dengan bercirikan sebagai berikut: mempromosikan konservasi alam, memberikan dampak sedikit mungkin terhadap lingkungan serta memberikan manfaat ekonomi bagi masyarakat setempat (Ceballos-Lascurain, 1996). Walaupun secara umum definisi tersebut telah mencakup pemberdayaan masyarakat setempat di mana kegiatan bisnis ekowisata dilaksanakan, namun cara-cara bagaimana memberdayakan masyarakat setempat untuk meningkatkan status masyarakat secara ekonomi belum mendapatkan perhatian yang selayaknya dari para peneliti, terutama di negara berkembang seperti Indonesia. Dampak negatif bisnis ekowisata dan wisata alternatif lainnya serta kemungkinan potensi ekowisata dalam pengembangan masyarakat daerah yang terbelakang masih sangat kurang (Scheyvens, 2000).

Melihat banyaknya potensi yang dimiliki oleh Indonesia, bukan mustahil akan memberikan berbagai dampak positif sebagai usaha pemberdayaan masyarakat pada masa yang akan datang, karena beberapa alasan, sebagai berikut:

1. Untuk meyakinkan bahwa keputusan kebijakan tentang pengembangan bisnis ekowisata masa depan merupakan cerminan dari pendapat para pelaku pariwisata.

2. Untuk meyakinkan terlaksananya manajemen yang baik terhadap aset-aset bisnis ekowisata di Indonesia, seperti misalnya sumber alam, karena 
bisnis ekowisata memang didasarkan pada keberadaan sumber alam tersebut.

3. Untuk meyakinkan bahwa bisnis ekowisata memberikan keuntungan secara ekonomis, sosial dan budaya terhadap semua pelaku bisnis ekowisata (stakeholders).

Zeppel (1999) secara lebih luas mendefinisikan ekowisata sebagai suatu kegiatan wisata yang berdasar pada sumber daya alam yang berkelanjutan dengan memasukkan juga unsur-unsur dinamika sosial dan budaya, di mana wisatawan berinteraksi dengan masyarakat lokal di taman nasional dan daerah-daerah yang belum banyak dikembangkan. Padahal menurut Sri Agus (1999), kegiatan wisata budaya di Indonesia kebanyakan masih berjalan apa adanya karena dipengaruhi oleh rendahnya sumber daya manusia dalam merencanakan suatu paket wisata budaya. Hal ini lebih dipersulit dengan rendahnya pemahaman masyarakat terhadap pengaruh negatif pada tataran individu, keluarga, serta masyarakat (Zeppel, 1999).

Selama ini pembicaraan mengenai pemberdayaan masyarakat lokal terhadap kegiatan bisnis ekowisata lebih banyak difokuskan pada masalah ekonomi, dalam kenyataannya pembangunan bisnis ekowisata itu merupakan kegiatan yang multidimensional, tidak hanya semata masalah ekonomi saja. Linberg (1999) mengemukakan bahwa bisnis ekowisata memiliki peran yang sangat besar dalam hal 'generating economic benefits' karena bisnis ekowisata ikut membantu penciptaan lapangan kerja di daerah terpencil yang secara ekonomis belum mendatangkan keuntungan baik bagi pemerintah maupun masyarakat. Meskipun kadang-kadang skalanya sangat kecil, tetap saja akan memberikan pengaruh yang cukup besar baik bagi individu maupun masyarakat. Lebih lanjut Linberg (1999) mengemukakan bahwa studi tentang bisnis ekowisata di Australia telah membuktikan adanya pengaruh positif dari sudut ekonomi, meskipun tingkat keuntungannya sangat bervariasi dari satu tempat ke tempat lainnya. Jika membicarakan masalah pemberdayaan ekonomi dari sudut pandang bisnis ekowisata, perlu kiranya dibicarakan sektor formal dan informal serta kesempatan berusaha yang tersedia, karena kegiatan wisata yang sifatnya musiman memberikan pengaruh yang cukup signifikan bagi masyarakat lokal. Terlebih lagi, sering terjadi ketidaksamaan pendapatan bagi orang-perorang yang dapat menimbulkan permasalahan (Wilkinson \& Pratiwi, 1995).
Pemberdayaan secara sosial didefinisikan sebagai suatu situasi di mana rasa kesatuan dan integritas sebuah kelompok masyarkat menjadi semakin kuat (Scheyvens, 2000). Fungsi bisnis ekowisata sebagai faktor yang menunjang pemberdayaan sosial sangatlah penting, karena dengan dibangunnya 'community- based tourism' akan memberikan pengaruh dinamika sosial yang cukup kuat bagi kelompok masyarakat tersebut. Akibatnya, anggota masyarakat akan merasa diikutsertakan dalam kegiatan bisnis ekowisata, yang berhasil. Pemberdayaan sosial yang bisa dilihat secara langsung dan tidak langsung dengan dilakukannya kegiatan bisnis ekowisata adalah semakin terbukanya kesempatan masyarakat setempat terhadap akses umum seperti misalnya air bersih, jalan yang semakin baik serta klinik-klinik kesehatan. Sedangkan dari perspektif budaya, Zeppel (1999) berpendapat bahwa bisnis ekowisata yang dikelola dengan baik juga memungkinkan untuk digunakan sebagai suatu sarana untuk mempertahankan keberadaan budaya asli penduduk setempat. Pemberdayaan sosial yang memadai terhadap masyarakat setempat memungkinkan mereka mempunyai kekuatan politis terhadap pembangunan fasilitas umum atau pembangunan bisnis ekowisata.

Kegiatan pariwisata sebagai salah satu alternatif untuk mendapatkan penghasilan bagi masyarakat dan devisa bagi negara sudah tidak diragukan lagi, meskipun di Indonesia sektor ini mengalami pasang surut. Seperti misalnya sebelum krisis ekonomi pariwisata menjadi sektor andalan bagi pemerintah karena memberikan kontribusi yang besar bagi perekonomian negara. Meskipun mengalami penurunan sejak terjadinya krisis sekaligus ketidakstabilan politik di Indonesia paling tidak 5 juta wisatawan manca dan lebih dari 100 juta wisatawan domestik tetap merupakan faktor penggerak ekonomi yang cukup signifikan di Indonesia. Dengan jumlah wisatawan mancanegara dan nusantara yang datang, maka sektor pariwisata tetap memberikan kesempatan kerja dan berusaha masyarakat Indonesia baik formal maupun non formal.

Untuk mengatasi penurunan jumlah wisatawan manca yang bersifat masal serta pemahaman pemerintah dan wisatawan terhadap dampak negatif pariwisata masal, akhir dekade ini telah dimulai kegiatan pariwisata yang mengarah pada Special Interest Tourism (SIT) yang ditandai dengan beberapa ciri khas di antaranya adalah berskala kecil, berkelanjutan, serta melibatkan masyarakat lokal sehingga memberikan dampak positif terhadap 
masyarakat sekitarnya. Keberadaan fasilitas untuk pariwisata masal seperti misalnya pembangunan kompleks, hotel di Nusa Dua, Bali ternyata akhirnya tidak memberikan pengaruh yang signifikan bagi masyarakat sekitarnya karena sebagian besar yang bekerja di bidang hospitality tersebut adalah masyarakat dari luat daerah tersebut. Hal ini juga terjadi di Phuket, Thailand di mana masyarakat lokal karena keterbatasan pendidikan dan pengetahuan serta kemampuan bahasa Inggris, kalah bersaing dengan pencari kerja dari luar wilayah Phuket (Thailand Tourism Authority, 2005).

Dikembangkannya SIT seperti misalnya Community-based ecotourism enterprises (Usaha ekowisata berbasis masyarakat) di Taman Nasional Gunung Halimun, akan memberikan manfaat ekonomis sebagai faktor pendorong utama, serta memberikan manfaat lain karena keterlibatan masyarakat lokal secara psikologis akan memberikan pengaruh kepercayaan diri yang besar bagi orang memberikan rasa tanggung jawab yang besar terhadap kelangsungan kehidupan di lingkungannya (Environmental Sustainability) (Scheyvens, 2000). Proses pengembangan bisnis ekowisata tersebut disyaratkan melibatkan masyarakat setempat tidak hanya dalam proses inisiasi tetapi pada tahapan pelaksanaan seperti pembangunan ecolodge (penginapan yang memenuhi persyaratan kelestarian lingkungan) di Gunung Halimun sejak awal telah melibatkan masyarakat secara aktif. Meskipun praktek di lapangan menunjukkan beberapa kendala yang dialami oleh fasilitator, tetapi keterlibatan masyarakat setempat sangat membantu mengurangi problem yang diasosiakan dengan pengembangan bisnis ekowisata.

Dalam skala yang lebih luas, peningkatan status sosial dalam masyarakat karena, berperan serta dalam masyarakat karena, berperan serta dalam kegiatan bisnis ekowisata ada dua yaitu secara langsung dan tidak langsung. Yang pertama misalnya dengan bekerja mereka mendapatkan keuntungan ekonomis sehingga kehidupan keluarga akan terjamin, sedangkan pengaruh yang tidak langsung termasuk kesempatan mendapatkan akses yang lebih bagus terhadap fasilitas-fasilitas umum seperti misalnya sarana, air bersih, jalan yang semakin baik serta akses terhadap klinik-klinik kesehatan. Bisnis ekowisata yang efektif sebagai kegiatan yang berbasis masyarakat semestinya memberikan keuntungan bagi masyarakat, karena sebagian dari kegiatan mereka disisihkan untuk kegiatan konservasi alam jika kegiatan bisnis ekowisata melibatkan alam sebagai basis kegiatannya. Kegiatan bisnis ekowisata berbasis masyarakat di Taman Nasional Gunung Halimun misalnya menyisihkan sekitar $10 \%$ hasil keuntungan untuk konservasi alam.

Namun untuk kelompok yang satunya, kendala yang dihadapi lumayan besar, karena mereka memiliki keterbatasan akses baik untuk akses produksi dan jasa serta akses pemasaran. Oleh sebab itu perlu ditingkatkan support dari pemerintah, tidak hanya untuk pengembangan produk tetapi pemasaran serta peningkatan kemampuan (skills) dengan cara training serta kursus sangatlah diperlukan. Hal ini akan meningkatkan kemampuan mereka dalam berproduksi sehingga kesejahteraan mereka akan lebih terjaga.

\section{KESIMPULAN}

Kualitas lingkungan, baik alamiah maupun buatan manusia, sangat penting bagi pariwisata, namun demikian keterkaitan antara pariwisata dan lingkungan yang mempunyai hubungan yang rumit. Membangun pariwisata mengharuskan banyak aktivitas yang dapat membawa dampak negatif bagi lingkungan. Kebanyakan dampak ini berhubungan dengan konstruksi infrastruktur umum seperti jalan, resort, hotel, restaurant, dan lain-lain. Dampak negatif pembangunan bisnis pariwisata jika tidak dilakukan secara hati-hati dapat merusak sumberdaya lingkungan di mana pariwisata itu bergantung. Untuk meminimalisasi resiko atau dampak negatif pembangunan pariwisata perlu dikembangkan sesuai keunikan dan kondisi wilayah yang ada. Hindari pembangunan industry pariwisata dengan hanya meniru atau mereplikasi industri pariwisata dari tempat lain. Konsep pengembangan pariwisata yang didasarkan pada keunikan dan kondisi wilayah dapat dikembangkan dengan mengimplementasikan pembangunan bisnis pariwisata ekologi (ecotourism) atau pembangunan pariwisata berkelanjutan (sustainable tourism development). Penerapan pembangunan pariwisata yang ramah lingkungan dan disesuaikan dengan keunikan dan kondisi setempat keberhasilannya dapat diukur melalui proses sosialbudaya yang berkelanjutan dan melibatkan jati diri masyarakat setempat; siklus sumberdaya alam dan lingkungan yang berkelanjutan; serta proses ekonomi yang dapat memberikan keuntungan secara berkelanjutan. Jika pendekatan bisnis pariwisata ekologi dan berkelanjutan diterapkan dengan baik maka industry pariwisata berpotensi untuk memberikan dampak positif yang menguntungkan bagi lingkungan melalui upaya-upaya perlindungan dan konservasi lingkungan di mana pariwisata dapat merupakan sumber untuk membiayai upaya 
perlindungan sumberdaya lingkungan dan meningkatkan nilai ekonomi sumberdaya/lingkungan, sekaligus pemberdayaannya dalam bidang sosial dan budaya masyarakat yang ada disekitarnya.

\section{REFERENSI}

[1] Ashley, C \& Roe, D. (1997). Community Involvement in Wildlife Tourism: Strengths, Weaknesses and Challenges. London: Evaluating Eden Project, International Institute for Environment and Development.

[2] Barkin, D. (1999). Ecotourism: A Tool for Suistanable Development. Available Online: http://www.greenbuilder.com/mader/Planeta/0596 .Download on 3/3/2019.

[3] Ceballos-Lascurain, H. (1996). Tourism, Ecotourism and Protected Areas. Gland, Switzerland: IUCN (World Conservation Union).

[4] Linberg, K. (2002). The Economic Impacts of Ecotourism. Available Online:http://ecotour.csu.edu.auecotour/marl.htm. Downloaded on 3/25/2019.

[5] Scheyvens, R. (2000). Promoting Women's Empowerment Through Involvement in Ecotourism: Experiences from The Third World. Journal of Suistanable Tourism, Vol. 8(3).PP. 232 -249 .

[6] Tourism Thailand. (2005). Bangkok Post, 19 October 2015.

[7] Zeppel, H. (2000). Ecotourism and Indigenous Peoples. Available Online:http://Lorenz.mur.csu.edu.au.ecotour/Downlo aded on 3/23/2019. 